\title{
UPAYA MEMBANGUN MINAT MEMBACA MELALUI PROGRAM BERAKSI (BERUGAK LITERASI) DI SMP ISLAM MUSTHOFA KAMAL
}

\author{
Aldi Albani \\ Manajemen Pendidikan Islam, STAI Darul Kamal NW Kembang Kerang, NTB \\ Email : aldialbani2@gmail.com
}

\begin{abstract}
Abstraksi
Rendahnya minat baca masyarakat Indonesia tampaknya ditanggapi serius oleh pemerintah dengan mengadakan program Gerakan Literasi Nasional. Hal ini tampaknya dimulai dari lembaga pendidikan baik di tingkat dasar, menenengah dan tinggi. Masalah utama dalam meningkatakan minat baca peserta didik khususnya di sekolah tentu bervariasi, adakalanya keterbatasan buku bacaan, tidak ada prasarana yang menunjang kegiatan membaca atau bahkan tidak ada guru yang bisa diteladani dan dapat menginspirasi peserta didik dalam membaca. Berbagai masalah itu coba diselesaikan dengan gerakan literasi di sekolah-sekolah. Begitu juga yang telah kami upayakan di SMP Islam Musthofa Kamal dengan mengadakan program BERAKSI yang bertujuan untuk merangsang kemauan siswa untuk terbiasa membaca dengan menfasilitasi mereka dengan prasarana khusus untuk membaca di sekolah. Metode yang penelitain dalam kajian ini adalah kualitatif deskriptif yang menggambarkan apa adanya dari pelaksanakan sebuah program. Teknik pengumpulan data yang digunakan adalah observasi dan dokumentasi. Analisis dilakukan sejak awal pelaksanaan pengamatan dengan menggunakan teknik Miles and Huberman. Adapun langkah-langkah dalam mewujudkan program tersebut di antaranya; perencanaan, pelaksanaan, evaluasi dan monitoring serta tindak lanjut. Adapun kesimpulan hasil program BERAKSI di SMP Islam Musthofa Kamal antara lain: 1) kemauan peserta didik untuk membaca mulai tumbuh; 2) berugak literasi selalu ramai dikunjungi oleh peserta didik pada jam-jam istirahat; 3) guru dapat memanfaatkan berugak literasi sebagai outdoor class; 4) guru dan staf menyempatkan diri untuk ikut membaca karena melihat peserta didik mulai ramai membaca; 5) perasaan senang dan gembira terpancar dari raut wajah peserta didik yang tengah membaca sambil sekali waktu bercerita dan bercengkrama dengan temannya di berugak literasi. Program BERAKSI merupakan salah satu upaya yang cukup efektif untuk menumbuhkan minat baca peserta didik di lingkungan sekolah.
\end{abstract}

Kata kunci: minat membaca, berugak literasi.

\section{Pendahuluan}

Membaca bagi sebagian masyarakat di Indonesia merupakan hal yang kurang menarik perhatian bahkan tidak disukai, padahal terdapat banyak manfaat dari kegiatan membaca. Manfaat tidak hanya dari segi kecerdasan untuk menambah wawasan semata, melainkan juga pada sisi sikap, nilai dan nurani. Manfaat membaca dari sisi kecerdasan di antaranya dapat meningkatkan pengetahuan, menambah kosa kata serta meningkatkan kemampuan berpikir kritis. Manfaat membaca dari segi sikap, nilai dan nurani adalah peningkatan kedewasaan dalam berpikir dan bertindak bagi seseorang, serta dapat menumbuhkan kepedulian terhadap sesama.

Praktik pendidikan yang dilaksanakan di sekolah selama ini belum dapat merepresentasikan secara utuh bahwa sekolah berfungsi sebagai lembaga pembelajaran 
yang membentuk semua warga sekolah sebagai pembelajar sepanjang hayat. Mengembangkan sekolah sebagai lembaga pembelajaran, dalam hal ini Kementerian Pendidikan dan Kebudayaan mengadakan program Gerakan Literasi Sekolah (GLS). Gerakan Literasi Sekolah adalah upaya menyeluruh yang melibatkan semua warga sekolah (guru, siswa, orangtua/wali murid) dan masyarakat, sebagai bagian dari ekosistem pendidikan. Peran aktif para pemangku kepentingan dalam pendidikan formal, yaitu khususnya kepala sekolah sangat berpengaruh terhadap pelaksanaan literasi di sekolah.

Gerakan Literasi Sekolah memperkuat gerakan penumbuhan budi pekerti sebagaimana dituangkan dalam Peraturan Menteri Pendidikan dan Kebudayaan Nomor 23 Tahun 2015 tentang Penumbuhan Budi Pekerti yang bertujuan untuk meningkatkan kualitas hidup, karakter bangsa, daya saing, serta melihat pengembangan keterampilan dan kompetensi yang dibutuhkan di era globalisasi saat ini diwujudkan dalam Gerakan Literasi Sekolah agar peserta didik menjadi pembelajar sepanjang hayat.

Atmazaki menjelaskan Gerakan Literasi Sekolah merupakan gerakan literasi yang aktivitasnya banyak dilakukan di sekolah dengan melibatkan siswa, pendidik dan tenaga kependidikan, serta orang tua. Gerakan Literasi Sekolah dilakukan dengan menampilkan praktik baik tentang literasi dan menjadikannya sebagai kebiasaan serta budaya di lingkungan sekolah. Literasi juga dapat diintegrasikan dalam kegiatan belajar mengajar di sekolah sehingga menjadi bagian tidak terpisahkan dari semua rangkaian kegiatan peserta didik dan pendidik, baik di dalam maupun di luar kelas. ${ }^{1}$

Pendidikan diselenggarakan sebagai suatu proses pembudayaan dan pemberdayaan peserta didik yang berlangsung sepanjang hayat. Pendidikan diselenggarakan dengan memberi keteladanan, membangun kemauan, dan mengembangkan kreativitas peserta didik dalam proses pembelajaran dan pendidikan yang diselenggarakan dengan mengembangkan budaya membaca, menulis dan berhitung bagi segenap warga masyarakat (UU No. 20 Tahun 2003, pasal 4). ${ }^{2}$ Jadi mengembangkan budaya literasi (membaca, menulis dan berhitung) sudah ada dalam sistem Pendidikan di Indonesia sejak tahun 2003, maka sebagai salah satu pengendali mutu layanan pendidikan harus terus melakukan optimalisasi pelayanan untuk meningkatkan mutu pendidikan yang jauh lebih baik.

Perkembangan pendidikan dituntut dapat memberikan pelayanan prima dalam menyiapkan ketrampilan abad 21 bagi peserta didik . Penyiapan keterampilan abad 21 bagi peserta didik menjadi tanggung jawab kita bersama sebagai komponen penjamin mutu Pendidikan. Pendidikan yang diselenggarakan harus dapat mewujudkan peserta didik yang literat sehingga mampu menghadapi tantangan masa depan untuk dirinya, orang tua dan masa depan bangsa ini. Salah satu upaya membangun budaya baca di

${ }^{1}$ Atmazaki, dkk, Panduan Gerakan Literasi Nasional, (Jakarta: Kementerian Pendidikan dan Kebudayaan, 2017), hal. 19

${ }^{2}$ UU Nomor 20 Tahun 2003 tentang Sistem Pendidikan Nasional. 
Jurnal At Tadbir STAI Darul Kamal NW Kembang kerang NTB

Volume 5 No 1 Tahun 2021

P-ISSN : 2580-3433

E-ISSN : 2715-7210

https://journal.staidk.ac.id/index.php/tadbir

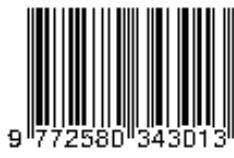

kalangan peserta didik adalah melalui pengelolaan yang tepat dan konsisten agar menjadi pembangunan budaya yang berkelanjutan serta dalam suasana menyenangkan.

Dikutip dari laman Kementerian Komunikasi dan Informatika Republik Indonesia tanggal 10/10/2017. UNESCO menyebutkan Indonesia urutan kedua dari bawah soal literasi dunia, artinya minat baca sangat rendah. Menurut data UNESCO, minat baca masyarakat Indonesia sangat memprihatinkan, hanya $0,001 \%$. Artinya, dari 1,000 orang Indonesia, cuma 1 orang yang rajin membaca. ${ }^{3}$

Riset berbeda bertajuk World's Most Literate Nations Ranked yang dilakukan oleh Central Connecticut State Univesity pada Maret 2016, Indonesia dinyatakan menduduki peringkat ke-60 dari 61 negara soal minat membaca, persis berada di bawah Thailand (59) dan di atas Bostwana (61). Padahal, dari segi penilaian infrastuktur untuk mendukung membaca, peringkat Indonesia berada di atas negara-negara Eropa.

Dihadapkan pada kenyataan bahwa penyelenggaraan pendidikan masih belum optimal dalam menyiapkan keterampilan abad 21 menjadikan peserta didik yang literat dengan identifikasi permasalahan-permasalahan di sekolah seperti: 1) minimnya tempat untuk melakukan aktifitas baca yang mudah dijangkau dan efisien waktu, 2) rendahnya minat membaca, menulis dan berhitung di kalangan peserta didik dan guru, 3) kurangnya pendampingan oleh guru dalam upaya membangun budaya baca di sekolah, 4) tidak optimalnya apresiasi dan penilaian guru terhadap peserta didik dalam meningkatkan kompetensi keterampilannya untuk membangun budaya baca, 5) tidak dilakukan monitoring dan evaluasi terhadap pelaksanaan program kegiatan pembangunan budaya baca untuk pengelolaan yang lebih baik.

Berdasarkan uraian di atas artikel ini kami beri judul "Upaya Membangun Minat Membaca Melalui Program BERAKSI (Berugak Literasi) di SMP Islam Musthofa Kamal.

\section{Kajian Pustaka}

Merujuk pada pemberitaan sebuah media online. Kompas.com tanggal 10/09/2019, 15:22 WIB. Organisasi Pendidikan, Keilmuan, dan Kebudayaan Perserikatan Bangsa-Bangsa (United Nations Educational, Scientific and Cultural Organization/UNESCO) menunjukkan data persentase minat baca anak Indonesia berada di angka 0,01 persen. ${ }^{4}$

Angka itu berarti, dari 10.000 anak Indonesia, hanya satu anak yang senang membaca. Tentunya hal ini sangat memprihatinkan. Tidak hanya itu, disebutkan juga bahwa minat baca di Indonesia menempati urutan ke-63 dari 70 negara. Oleh karena itu, orang tua memiliki peran penting untuk menumbuhkan minat baca kepada anak,

3 https://www.kominfo.go.id/content/detail/10862/teknologi-masyarakat-indonesia-malas-bacatapi-cerewet-di-medsos/0/sorotan media

$4 \quad$ https://edukasi.kompas.com/read/2019/09/10/15225581/3-hal-ini-jadi-penyebab-rendahnya$\underline{\text { minat-baca-anak-indonesia?page }=\text { all }}$ 
terutama anak yang masih berusia dini, demikian juga sekolah memiliki kewajiban untuk berupaya menumbukan minat baca peserta didik di sekolah.

\section{Pengertian Minat}

Dalam Kamus Besar Bahasa Indonesia kata minat memiliki arti kecenderungan hati yang tinggi terhadap sesuatu, gairah, keinginan. Jadi harus ada sesuatu yang ditimbulkan, baik dari dalam dirinya maupun dari luar untuk menyukai sesuatu. Hal ini menjadi sebuah landasan penting untuk mencapai keberhasilan sesuatu karena dengan adanya minat, seseorang menjadi termotivasi tertarik untuk melakukan sesuatu. ${ }^{5}$

Minat ditandai dengan ketertarikan akan sesuatu yang datang secara alamiah tanpa ada dorongan dari luar atau orang yang menyuruh. Artinya, harus ada kerelaan dari seseorang untuk melakukan sesuatu yang disukai. Dengan demikian, timbulnya minat terjadi karena adanya penerimaan akan suatu hubungan antara diri sendiri dengan sesuatu di luar dirinya. Semakin kuat atau semakin besar hubungan tersebut maka semakin dekat minat seseorang.

Adanya minat dalam diri seseorang juga dapat diungkapkan melalui pernyataan yang menunjukkan bahwa seseorang cenderung lebih menyukai sesuatu hal dari pada yang lain. Minat dapat ditunjukkan dalam avtivitas seseorang yang selalu melakukan apa yang ia gemari secara suka rela. Minat dapat pula diungkapkan dalam suatu aktivitas tertentu. Seseorang yang memiliki minat terhadap sesuatu akan memberikan perhatian lebih besar terhadap benda atau aktivitas tersebut. Misalnya dalam hal makan, meminum atau tertarik dalam suatu aktivitas tertentu seperti bermain musik, berenang dan membaca.

Ada juga pendapat yang mengartikan minat sebagai sumber motivasi yang akan mengarahkan seseorang pada apa yang akan mereka lakukan bila diberi kebebasan untuk memilihnya. Bila ia melihat sesuatu itu mempunyai arti bagi dirinya, maka ia akan tertarik terhadap sesuatu itu yang pada akhirnya akan menimbulkan kepuasan bagi dirinya.

Penulis dapat mendifinikan bahwa yang dimaksud dengan minat adalah rasa akan ketertarikan pada suatu benda atau kegiatan yang ditunjukkan dengan keinginan, kecenderungan untuk memperhatikan benda atau kegiatan tersebut tanpa ada seorangpun yang meminta. Hal ini dilakukan dengan kesadaran diri sendiri dan diikuti dengan perasaan yang senang. Minat bisa menjadi sumber motivasi seseorang, sehingga minat memiliki pengaruh yang cukup besar terhadap kegiatan yang dilakukan seseorang. Sama halnya dengan apa yang menajdi minat siswa tentu akan menariknya untuk melakukan hal tersebut dengan kesadaran mandiri dan perasaaan senang.

\section{Faktor yang Mempengaruhi Minat}

Minat tidak akan timbul, tumbuh dan berubah tanpa ada interaksi manusia terhadap objek tertentu. Hal tersebut mengandung arti bahwa minat terbentuk dalam

\footnotetext{
${ }^{5}$ Depdiknas, Kamus Besar Bahasa Indonesia, (Jakarta: 2001), hal. 744.
} 
hubungan dengan suatu objek. Minat pada dasarnya adalah penerimaan akan suatu hubungan antara diri sendiri dengan sesuatu yang ada di luar dirinya. Semakin kuat atau dekat hubungan tersebut, maka semakin besar minat.

Minat tidak dibawa sejak lahir melainkan diperoleh setelah ada interaksi terhadap objek tertentu. Mengembangkan minat terhadap sesuatu pada dasarnya adalah membantu siswa memelihara bagaimana hubungan antara materi yang diharapkan dengan manfaat bagi dirinya sendiri sebagai individu. Proses ini berarti menunjukkan pada siswa bagaimana pengetahuan atau kecakapan tertentu mempengaruhi dirinya dan memuaskan kebutuhannya.

Faktor timbulnya minat menurut salah seorang tokoh terdiri dari tiga faktor, yaitu; 1) Faktor dorongan dari dalam; 2) Faktor motif sosial; dan 3) Faktor emosional. Selain faktor-faktor di atas, kondisi seseorang juga sangat menentukan minat orang tersebut pada suatu aktivitas atupun benda, baik kondisifisik maupun psikisnya.

\section{Pengertian Membaca}

Dalam belajar bahasa dikenal keterampilan berbahasa ada empat macam yaitu ketrampilan menyimak, berbicara, membaca dan menulis. Membaca sendiri dapat dilihat sebagai suatu proses dan sebagai suatu hasil. Menurut Farida Rahim membaca pada hakikatnya adalah suatu hal yang rumit yang melibatkan banyak hal, tidak hanya sekedar melafalkan tulisan, tetapi juga melibatkan aktivitas visual, berpikir, psikolinguistik, dan metakognitif. ${ }^{6}$

Sedangkan klein yang dikutip Farida mengemukakan bahwa definisi membaca mencakup: (a) membaca merupakan suatu proses, (b) membaca adalah strategis, dan (c) membaca merupakan interaktif. ${ }^{7}$ Dalam hal ini yang dimaksud dengan membaca merupakan suatu proses adalah informasi dari teks pengetahuan yang dimiliki oleh pembaca mempunyai peranan yang utama dalam membentuk makna, membaca adalah strategi yaitu dalam kegiatan membaca kita harus menggunakan berbagai strategi yang sesuai dengan teks dan konteks dalam rangka mengkonstruksi makna ketika membaca. Sedangkan membaca adalah interaksi yaitu dalam proses membaca terdapat interaksi antara pembaca dengan teks yang dibacanya.

Menurut McLaughin dan Allen dalam Farida, mengemukakan bahwa prinsipprinsip membaca yang paling mempengaruhi pemahaman membaca antara lain sebagai berikut $^{8}$ a) pemahaman merupakan proses konstruktivis sosial, 2) keseimbangan kemahiraksaan adalah kerangka kerja kurikulum belajar siswa; 3) pembaca yang baik memegang peranan yang strategis dan berperan aktif dalam proses membaca, 4) membaca hendaknya terjadi dalam konteks yang bermakna, 5) siswa menemukan manfaat-manfaat membaca yang berasal dari berbagai teks pada berbagai tingkatan kelas, 6) perkembangankosakata dan pembelajaran mempengaruhi pemahaman

\footnotetext{
${ }^{6}$ Farida Rahim, Pengajaran Membaca di Sekolah Dasar, (Jakarta:Bumi Aksara, 2008), hal. 2.

${ }^{7}$ Farida Rahim, Op. Cit., hal. 3.

${ }^{8}$ Farida Rahim, Op. Cit., hal. 3-4.
} 
membaca, 7) pengikutsertaan adalah suatu faktor kunci pada proses pemahaman, 8) strategi dan ketrampilan membaca bisa diajarkan, 9) asesmen yang dinamis menginformasikan pembelajaran membaca pemahaman.

\section{Tujuan Membaca}

Membaca merupakan serangkaian kegiatan pikiran yang dilakukan dengan penuh perhatian untuk memahami suatu informasi melalui indra penglihatan dalam bentuk simbol-simbol yang rumit, yang disusun sedemikian rupa sehingga mempunyai arti dan makna. Membaca merupakan proses komunikasi. Dalam membaca terdapat aktivitas atau proses penangkapan dan pemahaman sejumlah pesan atau informasi dalam bentuk tulisan. Jadi, membaca adalah kegiatan otak untuk mencerna dan memahami serta memakanai simbol-simbol. Aktivitas membaca telah merangsang otak untuk melakukan olah pikir untuk memahami maknya yang terkandung dalam rangkaian simbol-simbol (tulisan). Semakin sering seseorang membaca maka semakin tertantang seseorang untuk terus berpikir terhadap apa yang mereka baca.

Aktivitas membaca sering dikaitkan dengan aktivitas berbicara, tetapi tidak semua orang yang melakukan proses berbicara mempunyai kesempatan untuk membaca. Oleh karena itu, orang lebih senang berbicara dari pada membaca karena membaca merupakan aktivitas yang kompleks. Ketika sebuah proses membaca sedang berlangsung, seluruh aspek kejiwaan dapat dikatakan ikut terlibat. Dalam aktivitas membaca, terjadi kemampuan berpikit dan proses mengolah rasa. Seorang anak yang sedang membaca berarti seoranga anak tersebut sedang membangun kepribadian dan sedang membangun kemampuannya dalam membaca.

Aktivitas membaca yang baik itu bukan hanya sekedar membaca, tetapi dalam setiap aktivitas membaca ini mempunyai tujuan yaitu untuk mendapatkan sejumlah informasi baru. Dibalik aktivitas membaca yang dilakukan oleh seseorang, terdapat tujuan yang lebih spesifik yaitu sebagai kesenangan, untuk meningkatkan pengetahuan dan untuk dapat melakukan suatu pekerjaan.

Menurut Dwi Sunar Prasetyono, ada beberapa tujuan dari aktivitas membaca, antara lain: ${ }^{9}$

a. Membaca sebagai suatu kesenangan tidak melibatkan proses pemikiran yang rumit. Aktivitas ini biasanya dilakukan untuk mengisi waktu senggang. Aktivitas yang termasuk dalam kategori ini adalah membaca novel, surat kabar, majalah atau komik.

b. Membaca untuk meningkatkan pengetahuan dan wawasan, seperti membaca buku pelajaran atau buku ilmiah.

c. Membaca untuk melakukan sesuatu pekerjaan atau profesi. Misalnya, membaca buku ketrampila teknis yang praktis atau buku pengetahuan umum (ilmiah populer).

${ }^{9}$ Dwi Sunar Prasetyono, Rahasia Mengajarkan Gemar Membaca pada Anak Sejak Dini, (Yogyakarta: Think Yogyakarta, 2008), hal. 60. 
Berdasarkan pada pendapat para ahli di atas, dapat disimpulkan bahwa tujuan membaca seseorang tergantung pada apa yang ingin dicapai. Tetapi tujuan dari membaca yang paling umum adalah untuk memperoleh informasi yang dapat digunakan untuk menjawab setiap permasalahan yang sedang dihadapi dan menambah pengetahuan bagi seseorang yang membacanya.

\section{Pengertian Minat Membaca}

Minat membaca pada anak tidak muncul begitu saja, tetapi melalui proses yang panjang dan tahapan perubahan yang muncul secara teratur dan berkesinambungan. Seperti halnya telah penulis uraikan diatas bahwa minat adalah suatu rasa lebih suka dan rasa ketertarikan pada suatu kegiatan atau aktivitas yang ditunjukkan dengan keinginan atau kecenderungan untuk memperhatikan aktivitas tersebut tanpa ada yang menyuruh, dilakukan dengan kesadarannya dan diikuti dengan rasa senang.

Menurut Farida Rahim minat baca adalah keinginan yang kuat disertai usahausaha seseorang untuk membaca. Seseorang yang mempunyai minat membaca yang kuat akan diwujudkan dalam kesediaannya untuk mendapat bahan bacaan dan kemudian membacanya atas kesadarannya sendiri. ${ }^{10}$

Dari pengertian di atas dapat disimpulkan bahwa minat membaca adalah suatu rasa lebih suka dan rasa lebih ketertarikan pada kegiatan penafsiran yang bermakna terhadap bahasa tulis (membaca) yang ditunjukkan dengan keinginan, kecenderungan untuk memperhatikan aktivitas tersebut tanpa ada yang menyuruh atau dilakukan dengan kesadarannya, diikuti dengan rasa senang serta adanya usaha-usaha seseorang untuk membaca tersebut dilakukan karena adanya motivasi dari dalam diri. Seseorang yang mempunyai minat membaca yang kuat akan diwujudkan dalam kesediaannya untuk mendapat bahan bacaan dan kemudian membacanya atas kesadarannya sendiri sehingga diperoleh makna yang tepat menuju pemahaman yang dapat diukur.

\section{Faktor yang Mempengaruhi Minat Membaca Siswa}

Membaca sangat penting bagi kehidupan manusia. Akan tetapi, kenyataanya bahwa banyak orang dewasa apalagi anak-anak atau siswa khususya siswa sekolah dasar belum menjadikan membaca sebagai suatu kebiasaan. Hal itu dikarenakan mereka belum menjadikan membaca sebagai suatu kebutuhan atau budaya. Minat membaca tidak hadir dengan sendirinya tetapi terdapat beberapa faktor yang mempengaruhi minat membaca.

\footnotetext{
${ }^{10}$ Farida Rahim, Loc. Cit.,
} 
Ada 3 faktor rendahnya minat baca: 1) Orang tua kurang menyadari bahwa membaca sejak dini itu penting. Orang tua sering menganggap bahwa masa kanakkanak adalah masa bermain sehingga masa kecil mereka dihabiskan untuk bermain bersama teman sebaya. Orang tua pun tidak memberi motivasi kepada anaknya untuk membaca paling tidak satu bacaan dalam sehari; 2) Perpustakaan sekolah menyediakan buku yang kurang menarik bagi anak-anak. Buku yang menarik bagi anak ialah yang mempunyai tampilan warna-warni dan beraneka macam gambar. Sementara itu, buku yang tersedia di perpustakaan sebagian besar telah usang, jenis tulisannya kecil, tidak terdapat gambar, dan hanya berupa narasi yang membosankan bagi anak; 3) Masyarakat kurang peduli untuk mendirikan taman bacaan. Jika ada taman bacaan yang didirikan di lingkungan sekitar, hal itu bisa mengundang anak untuk datang dan membaca buku yang menarik sesuai dengan usia mereka. ${ }^{11}$

Dari paparan diatas dapat disimpulkan bahwa minat membaca siswa dapat terbentuk karena adanya faktor yang mempengaruhinya. Faktor tersebut dapat berasal dari dalam dirinya (pembawaan/ bakat, jenis kelamin, tingkat pendidikan, keadaan kesehatan, keadaan jiwa, kebiasaan) dan faktor dari luar (buku/ bahan bacaan, kebutuhan anak dan lingkungan anak).

Farida Rahim mengemukakan bahwa minat baca ialah keinginan yang kuat disertai usaha-usaha seseorang untuk membaca. Seseorang yang mempunyai minat membaca yang kuat akan diwujudkannya dalam kesediaannya untuk mendapat bahan bacaan dan kemudian membacanya atas kesadaran sendiri atau dorongan dari luar. ${ }^{12}$

Hurlock mengemukakan bahwa minat sendiri terdiri dari dua aspek, yaitu aspek kognitif dan aspek afektif. ${ }^{13}$

\section{a. Aspek Kognitif}

Aspek kognitif didasari pada konsep perkembangan di masa anak-anak mengenai hal-hal yang menghubungkannya dengan minat. Minat pada aspek ini berpusat pada apakah hal yang diminati akan menguntungkan dan mendatangkan kepuasan pribadi. Misalnya kegiatan membaca, ketika siswa melakukan kegiatan membaca tentu saja mengharapkan sesuatu yang didapat dari proses membaca sehingga banyak manfaat yang didapat dari kegiatan membaca. Jumlah waktu yang dikeluarkan pun berbanding lurus dengan kepuasan yang diperoleh akibat membaca sehingga kegiatan membaca akan menjadi tetap, yang pada gilirannya ini akan menjadi sebuah kebutuhan yang sifatnya harus terpenuhi.

\section{b. Aspek Afektif}

Aspek afektif atau emosi yang mendalam merupakan konsep yang menampakkan aspek kognitif dari minat ditampilkan dalam sikap terhadap kegiatan yang diminati akan terbangun. Seperti aspek kognitif, aspek afektif dikembangkan dari

\footnotetext{
${ }^{11}$ https://edukasi.kompas.com/read/2019/09/10/15225581/3-hal-ini-jadi-penyebab-rendahnyaminat-baca-anak-indonesia?page=all

${ }^{12}$ Farida Rahim, Op. Cit., hal. 28

${ }^{13}$ Elizabeth B. Hurlock, Psikologi Perkembangan, (Jakarta: Gramedia, 1980), hal. 116.
} 
pengalaman pribadi, sikap orang tua, guru, dan teman yang mendukung terhadap aktivitas yang diminati. Siswa yang memiliki minat baca yang tinggi akibat kepuasan dan manfaat yang didapat serta mendapat penguatan respons dari orang tua, teman, dan lingkungan, maka siswa ini akan memiliki ketertarikan dan keinginan sehingga mau meluangkan waktu khusus dan frekuensi yang tinggi untuk membaca.

\section{Metode Penelitian}

Kajian ini merupakan penelitian kualitatif (qualitative research) yang bertujuan untuk menggambarkan dan menganalisis fenomena-fenomena, peristiwa, aktivitas sosial, sikap, kepercayaan, persepsi, pemikiran orang secara individu ataupun kelompok. ${ }^{14}$ Penelitian ini terdapat upaya untuk mendeskripsikan, mencatat, menganalisis dan menginterpretasikan kondisi-kondisi yang saat ini terjadi. ${ }^{15}$ Penelitian ini hanya akan mendeskripsikan fenomena yang ada secara mendalam apa adanya, maka penelitian ini adalah penelitian deskriptif (descriptive research). Jenis penelitian deskriptif ini disebut juga penelitian praeksperimen karena dalam penelitian ini mereka melakukan eksplorasi dan menggambarkan fenomena dengan tujuan untuk dapat menerangkan dan memprediksi terhadap sesuatu yang berlaku atas dasar data yang diperoleh di lapangan. ${ }^{16}$ Selain itu penelitian ini dilakukan dengan tujuan mengembangkan pengetahuan yang mendalam mengenai objek yang diteliti, sehingga sifat dari penelitian ini lebih banyak bersifat eksploratif dan deskriptif. ${ }^{17}$

Selain itu dalam penelitian ini juga terjadi proses pengamatan dan pemaknaan atas fenomena yang terjadi di lapangan. Oleh sebab itu, pengumpulan data dalam penelitian ini dilakukan melalui tiga cara yaitu pengamatan (observation) untuk memahami sikap/tindakan yang terjadi, dan dokumentasi yang bisa berupa tulisan, gambar, rekaman, dan lain sebagainya.

Analisis data adalah rangkaian kegiatan penelaahan, pengelompokan, sistematisasi, penafsiran dan verifikasi data agar sebuah fenomena memiliki nilai sosial, akademis, dan ilmiah. ${ }^{18}$ Analisis data untuk penelitian kualitatif dimulai sudah sejak di lapangan. ${ }^{19}$

Melihat penelitian kualitatif yang menggunakan logika induktif, maka konseptualisasi, kategorisasi, dan deskripsi dikembangkan oleh peneliti berdasarkan kejadian, peristiwa, dan fenomena yang ada di lapangan. Karena itu, antara proses pengumpulan data dan analisis data dalam penelitian ini menjadi satu kegiatan yang

\footnotetext{
${ }^{14}$ Nana Syaodih Sukmadinata, Metode Penelitian Pendidikan, (Bandung: PT Remaja Rosdakarya, 2006), hal. 60

${ }^{15}$ Sanapiyah Faisal, Metodologi Penelitian Pendidikan, (Surabaya: Usaha Nasional, 1982), hal. 42

${ }^{16}$ Sukardi, Metodologi Penelitian Pendidikan; Kompetensi dan Praktiknya. (Jakarta: Buni Aksara, 2003), hlm. 14

${ }^{17}$ Nurul Ulfatin, Metode Penelitian Kualitatif di Bidang Pendidikan: Teori dan Aplikasinya, (Malang: Bayumedia Publishing, 2013), hal. 48

${ }^{18}$ Imam Suprayogo dan Tobroni, Metodologi Penelitian Sosial-Agama, (Bandung: Remaja Rosdakarya, 2003), hlm. 191

${ }^{19}$ M. Djunaidi Ghony dan Fauzan Almanshur, Metodologi Penelitian Kualitatif; Edisi Revisi, (Jogjakarta: Arruz Media, 2012), hlm. 274
} 
integral dan sekaligus simultan. Peneliti akan mengikuti model Miles dan Huberman dalam melakukan analisis data. Data-data yang dianalisis melalui beberapa tahapantahapan, sebagaimana yang dikemukakan Miles dan Huberman (1984) bahwa aktivitas dalam analisa data, yaitu data collection, data reduction, data display, dan conclusion drawing/verification. ${ }^{20}$

\section{Pembahasan}

Berdasarkan permasalahan yang telah diuraikan di atas dengan mempertimbangkan berbagai keterbatasan yang ada di sekolah, maka strategi yang dilaksanakan untuk mengatasi masalah rendahnya minat peserta didik dalam membaca di sekolah adalah program BERAKSI, yakni singkatan dari "Berugak Literasi".

Program BERAKSI merupakan sebutan dari program "Berugak Literasi" yang bertujuan untuk memfasilitasi peserta didik di sekolah untuk mengakses berbagai macam buku bacaan di berugak-berugak yang ada di lingkungan SMP Islam Musthofa Kamal.

Langkah pertama dalam penerapan program BERAKSI adalah perencanaan. Kepala sekolah menyampaikan permasalah yang ada dan tawaran solusi yang akan dilaksanakan kepada dewan guru, komite sekolah dan pengurus yayasan pada rapat sosialisasi program. Pada waktu yang sama dibentuklah TPMPS sebagai panitia pelaksana program BERAKSI, kemudian disusunlah jadwal pelaksanaan program dan rencana anggara dan biaya pelaksanaan program.

Langkah selanjutnya adalah pelaksanaan program BERAKSI yang dilakukan sesuai dengan rencana dan anggaran yang telah disusun. Program ini dilaksanakan selama dua pekan mulai dari pembersihan lokasi sekitar berugak literasi dan pengadaan fasilitas buku bacaaan yang melibatkan semua warga sekolah dari unsur kepala sekolah, guru, staf, peserta didik, dan pengurus yayasan. Kegiatan ini dilakukan pada awal semester ganjil Tahun Pelajaran 2019-2020.

Setelah hampir satu bulan dari sejak perencanaan program BERAKSI, maka akhirnya selesailah pengadaan program BERAKSI, sehingga peserta didik dapat memanfaatkan brugak literasi sebagai sumber informasi dan sumber belajar setiap kali diperlukan meskipun masih dalam tahap permulaan dengan segala keterbatasan yang ada. Aktivitas baca peserta didik mulai terlihat dengan kehadiran peserta didik di brugak literasi pada jam-jam istirahat sekolah. Selain itu guru juga dapat memanfaatkan brugak literasi sebagai kelas luar ruangan (outdoor class) untuk melakukan pembelajaran yang lebih menyenangkan dan santai.

Langkah ke tiga dari program BERAKSI adalah evaluasi dan monitoring. Monitoring dilakukan oleh kepala sekolah selaku penanggung jawab program dilakukan sejak awal kegiatan dilaksanakan. Selain itu tim monev secara khusus melakukan tugasnya setelah program BERAKSI selesai dilaksanakan dengan memberikan berbagai masukan dan saran untuk meningkatkan mutu sekolah. Monitoring dan evaluasi juga

${ }^{20}$ Sugiono, Memahami Penelitian Kualitatif, (Bandung: Alfabeta, 2009), hlm. 91 
dilakukan oleh pengurus yayasan dan memberikan apresiasi dan dukungan terhadap program-program yang telah dilaksanakan dengan baik.

Langkah terakhir adalah tindak lanjut dari program BERAKSI. Melihat hasil yang cukup efektif dalam pelaksanaan program ini, maka kami selaku kepala sekolah tentu berupaya menyempurnakan berbagai kekurangan yang ada baik berupa masukan dan saran yang telah diberikan oleh berbagai pihak. Salah satu hal yang pling menonjol adalah kekurangan buku bacaan yang bervariasi sehingga kami merencanaakan penambahan koleksi buku untuk program BERAKSI. Gerakan Literasi Sekolah ini kami awali dengan segala keterbatasan dan akan terus menguatkan program literasi sekolah. Progam sebagai awal praktik baik dalam hal menumbuhkan budaya baca peserta didik untuk menjadikannya sebagai peserta didik yang literat sehingga apa yang telah kami laksanakan bisa dijadikan inspirasi oleh sekolah lain.

Hal yang tidak dapat dipungkiri adalah keberadaan faktor yang sifatnya dukungan dan hambatan dalam membuat sebuah program. Faktor pendukung yang menjadikan program BERAKSI ini terlaksana dengan cukup baik antara lain: 1) komitmen bersama terhadap mutu pendidikan untuk terus maju serta didukung penuh oleh pengurus yayasan; 2) kekompakan dewan guru dalam mengadakan dan melaksanakan program untuk memberikan pelayanan prima kepada peserta didik; 3) keikutsertaan peserta didik dalam merealisasikan, mendukung dan melaksanakan program BERAKSI yang pada dasarnya diperuntukkan bagi mereka; 4) ketersediaan dana untuk pelaksanaan program BERAKSI; 5) dukungan pengawas selaku tim yang melakukan monitoring dan evaluasi demi peningkatan kinerja sekolah.

Adapun faktor-faktor yang menjadi penghambat pelaksanaan program BERAKSI antara lain: 1) waktu yang relatif singkat dalam pelaksanaan program sehingga belum bisa berjalan optimal; 2) ketiadaan petugas khusus yang berpengalaman dalam mengelola buku di berugak literasi, sehingga peserta didik ditugaskan untuk melayani temanya sendiri secara bergiliran; 3) kurangnya buku bacaan dan buku pelajaran yang lebih bervariasi; 4) lokasi yang berada di luar ruangan menjadikanya kurang nyaman ketika datang musim hujan, mengingat perabot yang ada berbahan dasar kayu.

\section{Kesimpulan}

Kesimpulan hasil pelaksanaan program BERAKSI di SMP Islam Musthofa Kamal antara lain: 1) kemauan peserta didik untuk membaca mulai tumbuh; 2) berugak literasi selalu ramai dikunjungi oleh peserta didik pada jam-jam istirahat; 3) guru dapat memanfaatkan berugak literasi sebagai outdoor class; 4) guru dan staf menyempatkan diri untuk ikut membaca karena melihat peserta didik mulai ramai membaca; 5) perasaan senang dan gembira terpancar dari raut wajah peserta didik yang tengah membaca sambil sekali waktu bercerita dan bercengkrama dengan temannya di berugak literasi. 
Program BERAKSI memberikan gambaran bahwa salah satu upaya yang cukup efektif untuk memulai gerakan literasi sekolah dan menumbuhkan minat baca peserta didik di lingkungan sekolah adalah dengan membuat program berugak literasi.

\section{Daftar Pustaka}

Atmazaki, dkk. 2017. Panduan Gerakan Literasi Nasional. Jakarta: Kementerian Pendidikan dan Kebudayaan.

Depdiknas. 2001. Kamus Besar Bahasa Indonesia.

Faisal, Sanapiyah. 1982. Metodologi Penelitian Pendidikan. Surabaya: Usaha Nasional.

Ghony, M. Djunaidi dan Fauzan Almanshur. 2012. Metodologi Penelitian Kualitatif; Edisi Revisi. Jogjakarta: Arruz Media.

Hurlock, Elizabeth B. 1980. Psikologi Perkembangan. Jakarta: Gramedia.

Permendikbud Nomor 23 Tahun 2015 tentang Penumbuhan Budi Pekerti.

Prasetyono, Dwi Sunar. 2008. Rahasia Mengajarkan Gemar Membaca pada Anak Sejak Dini. Yogyakarta: Think Yogyakarta.

Rahim, Farida. 2008. Pengajaran Membaca di Sekolah Dasar. Jakarta:Bumi Aksara.

Sugiono. 2009. Memahami Penelitian Kualitatif. Bandung: Alfabeta.

Sukardi. 2003. Metodologi Penelitian Pendidikan; Kompetensi dan Praktiknya. Jakarta: Bumi Aksara.

Sukmadinata, Nana Syaodih. 2006. Metode Penelitian Pendidikan. Bandung: PT Remaja Rosdakarya.

Suprayogo, Imam dan Tobroni. 2003. Metodologi Penelitian Sosial-Agama. Bandung: Remaja Rosdakarya.

Ulfatin, Nurul. 2013. Metode Penelitian Kualitatif di Bidang Pendidikan: Teori dan Aplikasinya. Malang: Bayumedia Publishing.

UU Nomor 20 Tahun 2003 tentang Sistem Pendidikan Nasional.

https://edukasi.kompas.com/read/2019/09/10/15225581/3-hal-ini-jadi-penyebabrendahnya-minat-baca-anak-indonesia?page=all

https://www.kominfo.go.id/content/detail/10862/teknologi-masyarakat-indonesiamalas-baca-tapi-cerewet-di-medsos/0/sorotan_media 